\title{
The Assimilation of In-Laws: The Impact of Newcomers on the Communication Routines of Families
}

\author{
Carolyn M. Prentice
}

Although our popular culture stereotypes relationships with in-laws as problematic, these relationships have largely been overlooked by communication researchers. In contrast to existing studies focusing on dyadic relationships, this study looked at how in-laws are assimilated into the family group as newcomers, using structuration theory to examine how routines are reproduced in families. In personal interviews, participants described how their families had assimilated newcomers or how they themselves were received into their spouse's families. A thematic analysis revealed specific communication routines that had to be adjusted upon entry of newcomers, including conversational topics, expected amount of interaction, use of joking, and conversational styles. Adjustments to these routines, although difficult to negotiate because they were not openly discussed, helped to transform the family of childhood into the family of adulthood. Structuration theory would suggest that the perceived stress in relationships with in-laws occurs because newcomers upset the comfort of families by disrupting their communication routines.

Keywords: Structuration Theory; In-Laws; Assimilation; Socialization; Family

Families have routines that they have produced and reproduced throughout the course of their life together. According to structuration theory (Giddens, 1984), these routines create a sense of ontological security - a sense that all is right with the world, that this is how a family should conduct its daily life. When a family member introduces a new spouse into the family, routines are inevitably impacted. The negative stereotypes of in-laws presented in our popular culture, in part, construct our low expectations for relationships with in-laws. However, what may be problematic is not that in-laws themselves are problematic, but that families live within their own routines and expect the newcomer to adjust to the family's routines,

Carolyn M. Prentice (Ph.D., University of Missouri) is an Assistant Professor of Communication Studies at the University of South Dakota. Correspondence to: Department of Communication Studies, 316 Noteboom Hall, University of South Dakota, Vermillion, SD 57069, USA. Email: carolyn.prentice@usd.edu 
not recognizing that the assimilation of a newcomer is a two-way process (Anderson, Riddle, \& Martin, 1999). The newcomer brings expectations, routines, and innovations to the new family that may disturb the family's sense of ontological security, requiring the family and newcomer to learn new routines.

The purpose of this interpretive study is to examine how the assimilation of inlaws into a family requires the communication routines of both the newcomer and the family to be adjusted to accommodate one another. Previous studies have focused principally on the mother-in-law/daughter-in-law relationship and approached it from the perspective of a potentially problematic relationship (Cotterill, 1989; Duvall, 1954; Fischer, 1983; Limary, 2002; Pfeifer, 1989). In contrast, the present study included married and engaged couples, parents-in-law, and siblings-in-law of both genders and sought to understand the process of how newcomers are assimilated into the family group. Thus, I approached the subject of in-law relationships from a bona fide small group perspective, rather than examining dyadic relationships like most previous studies of communication among in-laws.

\section{Previous Studies of In-Laws}

Many researchers have noted that investigation of in-law relationships would yield useful understandings of American families. As early as 1954, Evelyn Duvall bemoaned the lack of research into in-law relationships and suggested that American understandings of in-law relationships might be changing and, therefore, worthy of study (Duvall, 1954). Many of the changes she pointed out in 1954 remain true today. For example, Duvall pointed out that because modern families are smaller, parents experience the empty nest sooner and may want to continue a close family relationship with their married children. Also, our modern focus on psychological understanding of people has led to a different view of intra-family contact: less of an obligation, and more emphasis on personal growth and fulfillment. In addition, parents are expected to live longer and, with pensions, social security, and insurance, are better able to take care of themselves and plan for their retirement, rather than relying solely on their children for support. Thus, the fear of "having to take care of Mom and Dad" has waned to some extent, so parents, parents-in-law, and children can enjoy each other as people, not obligations (Duvall, 1954). As Duvall stressed in 1954, in-law relationships in the United States remain in flux but are, nevertheless, important in our understanding of marriage. In the 50 years since Duvall's seminal study, various other family scholars have reiterated Duvall's call for more research into the relationships among in-laws (Bengston, 2001; Lopata, 1999; Norris, Pratt, \& Kuiack, 2003).

Most of the research into these relationships has focused on the mother-in-law, usually the mother of the husband, as the most problematic in-law. Duvall's original prompt to a radio audience, "Why I think mothers-in-law are wonderful people," elicited over 3000 positive responses. Nevertheless, in follow-up interviews and group discussion with 1337 participants, Duvall found that the mother-in-law was considered the most troublesome in-law. Later studies reported that this tension 
between the wife and the mother of the husband developed, in part, because daughters preferred to remain closer to their own mothers while the husband's mother was often perceived as criticizing and intrusive (Cotterill, 1989; Fischer, 1983; Jackson \& Berg-Cross, 1988; Limary, 2002; Pfeifer, 1989). However, some researchers have suggested that other in-laws can be problematic, particularly the father of the wife (Nydegger, 1986) or siblings of the spouse (Duvall, 1954; Silverstein, 1990). In general, researchers have principally focused on the negative feelings between specific in-laws, although they have recognized some positive dimensions to these relationships (Cotterill, 1989; Fischer, 1983; Jackson \& Berg-Cross, 1988).

According to the family life cycle perspective (McGoldrick, 1989), newlyweds must establish new relationships with their parents while also establishing themselves as a separate unit. However, little consideration has been given to the parents and siblings of the newlyweds and how their nuclear family life is affected by the new in-law. Indeed, the stages of family life concerned with assimilating newcomers are named launching and the empty nest, terms which seem to focus on losing family members rather than adding them (Carter \& McGoldrick, 1988). Since there is no specific ritual of assimilation into a family in the United States, other than the marriage ceremony itself (Pfeifer, 1989), new in-laws are forced into relationships that have no clear-cut roles or expectations (Pfeifer, 1989; Servovich \& Price, 1994). Family scholars have researched how different communication styles are negotiated between couples and within families, focusing principally on the relationships between the married couple themselves, or between the couple and its minor children. Critical to these findings is that marital satisfaction is highest among couples who have similar communication styles (Fitzpatrick, 1988).

Because much of the research into in-laws has focused principally on dyadic relationships, the process of how new in-laws are assimilated by the whole family as a small group has received little attention as a separate process. Although Cotterill (1989) noted that "The extended family is an agent of adult socialization which is wholly different from the socialization of the child" (p. 571), she did not explore this socialization process in depth. Instead, she reported that the patterns that develop during the courtship period lay the foundation for subsequent in-law relationships. Cotterill did not study the impact that in-laws other than the mother-in-law may have on the assimilation of the new family member. Similarly, Pfeifer (1989) limited her exploration of socialization to the first meeting between mother-in-law and daughter-in-law, without probing how the socialization process continued, which of the other family members might be agents of this process, and how the entry of the new in-law affected the whole family. In addition, other than Jorgenson (1994) and Limary (2002), communication scholars have not explored communication in relationships among in-laws. In general, research into in-law relationships has not been approached from a small group or a communication perspective. 


\section{Theoretical Foundations}

Small group scholars have called for researchers to move away from studying ad hoc, zero-history laboratory groups and, instead, to focus on bona fide groups in natural contexts (Frey, 1994a,b; Socha, 1999; Stohl \& Putnam, 1994). This call has fostered the recognition that families are small groups and that our understanding of families is limited because we have not studied them as groups (Socha, 1997; Stafford \& Dainton, 1995). Socha (1999) proposed that what we learn from families may be applicable to all groups, and that what we already know about groups may be applicable to families. He also called for researchers to widen the diversity of family groups studied and to study them as a whole, rather than just studying the individual relationships within them. Similarly, Barker et al. (2000) suggested that structuration theory (Giddens, 1984) be used to explore how the underlying routines of a family maintain and reproduce family systems. Keyton (1999) noted that the routine communication within families is relational, not task-oriented, which may be true of other bona fide groups. Frey (1994a) noted that studying the socialization of family members might yield useful insights into both families and small groups.

Structuration theory posits that social activity consists mostly of day-to-day routines that are both the medium through which humans create their social structures and also the outcome - that is, the social structure that is created (Giddens, 1984). In enacting structures in their lives, human beings follow their memories of what they have always done, their routines, which make everyday life and interactions predictable and comfortable, giving them a sense of ontological security (Giddens, 1984). Within the confines and guidelines of their social structures and routines, human actions then reproduce those routines, thus maintaining that security.

People do not reproduce the same routines mindlessly. Structuration theory proposes that individuals make choices and act because they possess three kinds of knowledge: (a) practical knowledge learned from the experience of everyday routines and norms; (b) rationalized knowledge acquired when they monitor their own behavior and explain it to others; and (c) knowledge of the motivation for their actions, which is usually an unconscious response to the unacknowledged conditions within which they must act (Giddens, 1984). These three kinds of knowledge outline the emerging levels of understanding that people experience as they adjust their routines to assimilate a newcomer.

Routines, then, form the foundation of family interactions. Socha (1997) has suggested that communication patterns - good or bad-may persist within families for generations, but he does not take into account that families expand by assimilating newcomers. Since the process of assimilation into a group is a twoway process (Anderson et al., 1999; Moreland \& Levine, 1982), the entry of the newcomer into a family may disrupt its routines as well as present the newcomer with new routines. Both the newcomer and the family may experience a disruption to their ontological security, which may be the main source of tension in relationships among in-laws. Family members may need to mobilize all three levels of knowledge to understand and adjust to the changes within their families. To explore the 
communication routines of both families and the newcomers, I ask the following research questions:

RQ1: How does the family as a group assimilate the newcomer in-law through its communicative behavior?

RQ2: How does the newcomer influence the communication routines of the family?

\section{Methods}

With the approval of my campus institutional review board, I conducted and transcribed interviews with 42 participants and then, after transcribing the tapes, thematically analyzed the resulting 534 single-spaced pages of transcripts.

\section{Interpretive Paradigm}

Interpretive research posits that reality is constructed by the participants and, therefore, seeks to understand how participants experience and interpret the events in their lives (Burrell \& Morgan, 1979; van Manen, 1990). Through a series of active interviews, I explored with the participants how they experienced assimilation of the newcomer into the family and how their communication routines were affected. Interpretive research asks questions of meaning, exploring the significance of individual experiences, rather than seeking solutions to specific problems (van Manen, 1990). According to Holstein and Gubrium (1995), one of the purposes of an active interview is to ask the participants to assume different perspectives, to look at their experiences in new ways. Thus, I asked the participants in this study not only to tell me stories of how they interacted with their new in-laws, but also to consider their experiences from different perspectives. This technique often led to new insights during the interview and a new construction of the meaning of their experiences they had not previously considered.

\section{Participants}

The participants were recruited through my acquaintances as well as their acquaintances and family members, therefore comprising a snowball sampling. All participants had acquired in-laws within the last five years or would acquire them through a marriage to take place within six months. Thus, all participants were in the process of assimilating and/or being assimilated as in-laws. Specifically, the 42 participants (28 women, 14 men) represented three different groups: Group 1 consisted of 12 women and six men who had been married within the last five years or who were engaged to marry within six months. Five married pairs participated while the other eight participants did not include their spouses or fiancé(e)s. All of these participants were between the ages of 22 and 32. Group 2 consisted of seven women and five men whose children were newly married or engaged to be married. These participants were all over 40 years old, with two of them over 55. Group 3 consisted of nine women and four men whose sibling was newly married or engaged 
to be married; all were between the ages of 18 and 24. One participant in Group 3 was also engaged to be married, and he was included in both Groups 3 and 1, but not counted as two participants.

I conducted the interviews at a place convenient to the participants, usually a public setting such as a coffee shop or lobby of a public building; however, five participants invited me to their homes. I began the interview with a series of questions about the specific in-laws we would be discussing, how long the interviewees had known the in-laws, and how frequently the interviewees and inlaws interacted. Then, I began the open-ended questions which asked the participants to describe their first meeting with the in-law, their present relationship with the in-law, changes in that relationship, and their reaction to the engagement. In addition, I asked them to describe typical family events that included the in-law, their expectations for a relationship with the in-law, what they had done to help the in-law adjust to his/her entry, and one thing they wished they could change in their relationship with the in-law. For the newly married participants, I asked forms of these questions regarding their entry into their spouse's families as well their spouse's assimilation into their families of origin. In general, the interviews ranged from 30 to 90 minutes, with the newly married participant interviews being the longest.

Although I interviewed individuals, I explored the impact of the newcomer on the entire family group. Beyond the design of the questions themselves, which probed into the relationship of the group with the in-law, my choice of participants also ensured that I was not examining only particular dyadic relationships. For example, through the testimony of the five married couples, I was able to explore how both the newcomer and his/her spouse viewed the impact on the family. In addition, in three cases, I interviewed the parents-in-law of particular participants, so I gained a broader perspective of the newcomer's impact on the group dynamics of the family. Thus, the study represents a bona fide group perspective rather than individual relationships.

\section{Thematic Analysis and Verification}

In qualitative research, Strauss and Corbin (1998) recommend that the analysis of the data be continuous, beginning in the collection stages and finishing only when the final report is written. As a conscientious interviewer, I began thematizing the data during the interview itself, by connecting ideas and probing for more details on particular productive themes that I identified while the participant was speaking (Holstein \& Gubrium, 1995). I also made notes after each interview, recording my general impression of the interview and how it enlarged my vision of the in-law relationship, similar to what van Manen (1990) terms the wholistic approach to thematizing. Then, I continued thematizing as I transcribed the interview tapes, making notes about possible themes which I sometimes used to direct my probing questions during subsequent interviews with different participants. 
After each interview was completed, transcribed, and checked for accuracy, I used Nvivo software, a qualitative research analysis package, to take what van Manen (1990) terms the selective approach, which involves reading the individual transcriptions and tentatively identifying the theme of specific passages by coding them as belonging to a particular theme. The Nvivo program allows the user to code and store specific passages for later retrieval. I created new themes as needed, generating a total of 68 , with many passages cross-coded.

To continue this process, I returned to the Nvivo program and retrieved the passages coded as a particular theme. I sorted through these groups and recoded some, created some new groups, and merged others, allowing the themes to emerge from the data, rather than imposing set themes upon the data. After identifying tentative themes, I read through the interviews and the themes several more times to see if other themes emerged or merged. When the themes seemed to overlap, I collapsed them into one group or found a different way of sorting them. Through this rather tedious process, I became intimately familiar with the interviews.

I ensured theoretical saturation (Strauss \& Corbin, 1998) in two ways. First, after I had met my minimum target of 10 participants for each group, several more individuals volunteered to participate. I included them in the study and found that their experiences reflected the themes that were emerging from the previous participants' interviews. Still later, after I had completed the majority of my thematic analysis, I recruited more male participants; however, no new themes emerged from these new data. Indeed, the additional participants corroborated the themes that had already emerged in the analysis and presented different exemplars of those themes; however, they did not introduce any new themes. Thus, I achieved theoretical saturation.

The two methods I used to verify my results included rich, thick description and member checking (Creswell, 1997). The findings below are reported with detailed and extensive quotations from the participants rather than short quips taken out of context. For member checking, after I had completed my analysis, I contacted four participants and summarized the themes that had emerged. They all concurred that the themes reflected their in-law experiences.

\section{Findings}

In their interviews, the participants described how they and their families had adjusted to becoming in-laws, using their everyday routines as both the medium for that adjustment and the outcome of that adjustment. In general, they reported good relationships with their in-laws. Their descriptions of group interactions illustrated how relational communication, rather than task-oriented communication (Keyton, 1999), is the main component of family life. They enacted and adjusted their routines to maintain, restore, or achieve ontological security in their families. 


\section{Communicating Norms and Routines to Newcomers}

Families communicated their norms and routines to newcomers in a variety of ways that can be classified as indirect or direct. In the most common indirect method, the family group simply carried on with its everyday routines and expected the newcomer to adjust because the family felt that its routines would be comfortable to the newcomer. Most of the participants found this to be an acceptable way to assimilate the newcomer because the families expected their members to make good choices of partners and bring in only those newcomers who would fit in with the group. As one mother-in-law commented, "I guess we just kind of did what we always did, and figured he'd learn to like it." Similarly, a newlywed man found, "[T] he thing that was the easiest is that [my in-laws] included me in everything. ... And so that was probably the very, the best thing that they did, was just being very inclusive and open with me." When the family routines were similar or a welcome change for the newcomer, initial assimilation of the newcomer was easy, and the newcomer usually felt welcomed, included, and accepted. These families were operating under their practical knowledge of everyday routines and norms. They did what they always did, not feeling the need to explain their routines to the newcomer.

However, perceived differences in family routines could make the newcomers confused and anxious because they did not experience the expected comfort of family. In some cases, families had to communicate directly to the newcomers about the norms and expectations in their families, thus demonstrating their rationalized knowledge about their routines. For example, fathers directly communicated to their future sons-in-law regarding their expectations for taking care of their daughters. This often occurred in the meeting with the father in which the son asked for permission to marry the daughter. One father-in-law, who discovered that his future son-in-law did not join in many family routines, recounted specifically outlining his expectations to the young man: "I understand that your family dynamic is different from ours. But you know, we'd like to see more of you." Another participant recounted a similar direct communication about family routines: "For a long time, [my brother-in-law] would never make eye contact with anybody.... My dad actually talked to him about it one time and told him to start looking at people." These direct messages reflected their rationalized knowledge about their family's routines and what behavior they felt they could accept to maintain the routines of their families.

Participants also recognized that some of their expectations for routine in-law relationships had been communicated to them indirectly through messages from their acquaintances and the media. These messages influenced the way they approached assimilation, making them monitor their own behavior toward their new in-laws. All participants recognized that media and popular culture portrayals of in-laws were usually negative, and they hoped their own experience would be different. Many participants also expressed low expectations for in-law relationships because they or a family member had unsatisfactory relationships with their in-laws or, in several cases, their own parents had been problematic as in-laws. For example, 
one woman who had endured her mother's disapproval of her husband vowed to never say anything that would cause problems in her daughter's marriage. She had experienced firsthand how a toxic in-law relationship could taint a marriage, and she wanted to break that cycle with her own daughter. Parents-in-law who had endured poor in-law relationships with their own parents-in-law were crusaders wanting to create good relationships with their child's spouse by not communicating too many norms and routines.

Another indirect method of communicating was the widespread practice of mediating the relationship between the newcomer and the family through the spouse, especially when dealing with problematic issues concerning routines. The usual practice was that the family communicated through the spouse rather than directly with the newcomer, although, in two cases, the mediator was a sibling-in-law. This mediation was a form of passing on the rationalized knowledge about the families' routines, and the practice itself became routine for several reasons. First, parents- and some siblings-in-law reported that they found it difficult to establish a direct relationship with the in-law because he/she was always with the spouse. Sometimes, this was because the married pair preferred to be always together and did not seem to want to establish separate relationships with the in-laws. Another reason for the mediated relationship was personality differences in shyness and talkativeness, which will be discussed later. Others, from previous negative experiences, had learned to fear direct private communication with the in-law. For example, one engaged woman had endured hostile remarks from her fiancés parents throughout their courtship. As she and her fiancé approached marriage, she avoided being alone with her future motherin-law: "No, I am deathly afraid of that. I request that [fiancé] is there all the time. I just can't even imagine how [my future mother-in-law] would let loose when he's not there for extended periods of time." Thus, many newcomers preferred to have a mediated relationship because they were shy, afraid, or different from their in-laws and felt insecure interacting with the in-laws directly or alone.

On the other hand, many participants felt that the child-in-law, parents-in-law, or siblings-in-law preferred the relationship to be mediated, as described by one newlywed: "I really don't want to see them alone. ... I guess one part of it is I'm not sure that they want to see me without him." Another newlywed described how she rarely telephoned her in-laws:

Usually, if we need to talk to [my parents-in-law], [my husband] will call. ... And and I'll talk to them if they call, but I don't, I don't call them very often. ... I guess just because I figure they're his parents.

These daughters-in-law felt that their parents-in-laws were not interested in talking to them directly, that the parents really preferred to communicate directly with their sons. On the other side, parents-in-law also felt that their children's spouses did not desire a direct relationship with them. For example, even though one mother-in-law made a special effort to have lunch with her daughter-in-law alone, her son also always ended up coming along because the daughter-in-law invited him. In many cases, this mediation maintained the routine of direct communication between the 
child and parent, which seemed to bring them the comfort of established close relationships; thus most participants did not complain about the practice.

Another form of this routine was that the spouse was expected to mediate the relationship with his/her family of origin on problematic issues. In some cases, these issues came up when the in-law did not understand the family expectations, and the spouse was expected to explain them to him/her. For example, this newlywed explained how his wife mediated a disagreement about celebrating a holiday:

It wasn't [my mother-in-law] and I face to face, but it was like [my mother-in-law] pretty much saying to [my wife], "Well, here's what you're going to do, and you can't do this." ... And then it's me turn around and saying, "Well everyone can stuff it." ... I think there was, might have been some yelling, but it wasn't two people yelling at each other; it was some yelling here, and then some yelling there.

With other couples or at other times, the issue that needed mediation was that the child had grown and changed, but had not addressed or renegotiated those changes with the parents, so the newcomer was sometimes blamed for changing the child. In these cases, the newcomer expected the spouse to mediate the relationship by confessing to the change in values or opinions. For example, one newlywed woman reported that her conservative in-laws were shocked when she discussed her views on abortion. Their son had never expressed such views, so the parents-in-law believed that somehow the new wife had changed their son. The wife then encouraged her husband to speak openly about their shared opinions so that she would not be blamed. This mediated relationship forced the man to be honest with his parents about how he had changed and grown, rather than allowing his wife to be blamed.

This mediation between spouse and parents on problematic issues was considered good practice, to keep the relationships cordial between in-laws, as one newlywed expressed:

If there's an issue that comes up ... I kind of see that as [my husband's] responsibility to handle. ... It's his dad; he should handle it. If my mom creates a problem, I'll handle it.

The mediated relationship also maintained the routine of a close relationship with the child or parent, and when time and contact were limited between them, they seemed to prefer to communicate directly, to return to the familiar routines of their family life. However, participants also recognized that they were missing out on a closer relationship with their in-law.

The other direct means of communicating family routines occurred when the family members explained their past and present relationships in the family so that the newcomer would understand the motivation behind the routines. For example, most participants described being briefed on family relationships before big group gatherings, and also being told family stories while looking at family pictures. For example, a newlywed man understood his in-laws' dynamics better when he was told that, because his wife's aunt could not have children, she doted on his wife and would always be included in all family gatherings. Another newlywed reported that seeing pictures of her husband as a child with his biological father helped her talk with her 
mother-in-law about this absent parent. All reported that this information was useful and helped them to understand why some members were treated in specific ways and why routines crystallized into specific behaviors and expectations.

These different ways that families communicated their routines represent the different kinds of knowledge that underlie people's routines (Giddens, 1984): practical knowledge, rationalized knowledge, and the knowledge of the motivation of action. In adjusting to the newcomers in their families, participants were called on to examine the motivation behind their routines, rather than simply enact them with the newcomer. The participants' experiences attest to the idea that the entry of newcomers disturbs a family's ontological security not only by changing the family routines, but also by making the family question the motivation behind their routines.

\section{Communication Routines Needing Adjustment}

Many participants reported that most of the family routines that required adjustment were not physical, but involved communication norms for family interactions. These norms included amount of interaction, acceptable level of emotional response in interactions, the topics considered suitable for discussion, different patterns of reserve, and interaction styles. These communication routines were more difficult to articulate and negotiate than physical routines because they reflected more deeply embedded family values, which were often not consciously considered or recognized.

The bona fide group perspective recognizes that group members are simultaneously members of other groups, which was an important consideration in this study. Newcomers were outsiders from other families, and families differed significantly in how much they wanted to interact. Sometimes when families were problematic, the children broke off relationships with their parents or in-laws when they married and created a routine of avoidance - a response reported by four participants. Other families accepted their children as adults having other obligations to work, friends, and spouses, as well as to other in-laws, and, therefore, relaxed their expectations. Some families expected the newcomer to maintain the routine of regular contact with their families because this routine was foundational to their feelings of family. In cases where the expected amount of interaction differed between families, in-laws reported stress in negotiating these routines. For example, a fatherin-law described how his son-in-law had a different expectation for amount of family contact: "Getting together doesn't seem to be a priority in [son-in-law's] family. ... They're all on good terms with one another, but in our family, if one person's doing something kind of significant, everyone will know about it." Although this father-inlaw recognized the difference between the families, he still hoped that his son-in-law would learn to interact more.

These differences in expected amounts of interaction between families created the most common stressor for newlyweds - that of having to negotiate how much time and contact to allot to each family - a stressor reported by almost all participants in this study. Both families wanted to see their married children and desired more 
contact with them. Some participants described how they or their parents felt jealous of the time the newlywed pair spent with the other family. For example, a mother-inlaw wanted to see more of her married daughter who lived right next door to her husband's parents: "[I wish they] would live closer so we would see each other more. I'm a little envious. I would prefer they lived in my backyard instead of his parents' backyard." In contrast, a newly married daughter was surprised that her parents were envious of the time she spent with her husband's family:

[My parents] raised me to be independent. ... So the fact that [my husband] would want to go home almost every weekend ... hurt my parents' feelings ... because I would be there and not with them.

This difference in family expectations of interaction created a high degree of conflict for the newlyweds in this study - a fact that was recognized by almost all participants. Nevertheless, even if they spent an adequate amount of time with each family, other communication routines needed to be adjusted.

Families had different norms for how much emotional display was acceptable in their interactions. Some families had a routine of openly expressing emotion, which made the less expressive newcomer feel uncomfortable and unable to live up to the family's expectations. For example, one newlywed man dreaded announcing the engagement to his fiancée's parents - even though it was expected-because her family responded to everything very emotionally:

It will be a big deal because [my wife] and her mom and all her sisters, they're very very emotional. They react to everything very strongly.... There's always either crying ... or screaming or hugging ... there's no such thing as a little deal.

In contrast, a newlywed woman explained how the routine in her family of origin was different from her husband's family in terms of physically and verbally expressing affection:

My family [hug and touch each other].... His family is not at all that way. They rarely say "I love you" to one another, whereas with my family, we're just all the time, "Love you, love you."

When this woman married into the family, however, she began hugging everyone, and the family responded by becoming more demonstrative themselves. Thus, the family routine was adjusted to accommodate the newcomer.

In contrast, sometimes the norm for less emotional display was not adjusted and became a source of discomfort between in-laws. For example, one mother-in-law was stunned by her son-in-law's emotional outburst over a minor injury:

And he starts really throwing a fit kind of loud. ... He's really fussing. ... And I just, I don't deal well with whining. I mean, our kids didn't whine when they were little. You know, this is an adult. Don't whine.

Having raised her own children to restrain themselves emotionally, this mother-inlaw was surprised to find that her daughter had married a man who did not restrain his emotions. In most cases, families and newcomers had to learn to accept and 
function with each other's level of emotional display because it was not something that could be negotiated, much less discussed.

In many families, some topics were considered taboo for conversation, so when newcomers joined the families, they sometimes brought up topics that were routinely not discussed in that family or, on the other hand, found themselves bewildered by the topics that were routinely discussed. Often, these encounters caused discomfort and left the participants uncertain about how to communicate their discomfort. For example, one mother-in-law was embarrassed when her new daughter-in-law talked about sex:

Of course that's not a discussion I would have with [my son] very often, and I certainly did not have it with her while she was dating my son! ... I don't want [my son] to feel like, "My mommy knows what I'm doing!"

In contrast, a newlywed woman who came from a politically liberal family found that what she considered normal political discussions became arguments with her inlaws who were politically very conservative. Thus, she did not know what to talk about with her in-laws because her own family of origin had routinely talked about politics. Another mother-in-law realized that her communication routine included having deep conversations; thus, she felt rejected when her daughter-in-law did not want to discuss her family history. In these instances, the participants found that their conversation topics needed some adjustment in the interactions with their in-laws, although they were not always sure how to effect that change.

Another difference among the families in terms of communication routines was in the variety of techniques used to conduct conversations. All participants described how conversation was the main activity when they got together with their families and in-laws, reflecting Keyton's (1999) assertion that relational messages are the foundation of bona fide group life. How the families managed those conversations differed among the participants. Several participants noted that the differences in their family communication routines were directly related to the difference in the sizes of their families. For example, one participant's family consisted of only her parents, one set of grandparents, and her aunt and uncle, so they were all expected to engage in a single conversation at family gatherings. In contrast, her husband's family consisted of around 40 people with children running around, and diverse conversations and activities. As she described it:

I grew up around adults pretty much, and so [my family celebrations are] kind of a big adult thing. ... I still like my little group of eight people better than the group of 40 . And I think he kind of likes the group of 40 with all the kids better than the eight.

Participants coming from smaller families had to learn how to seek out dyadic conversations in large groups, while participants from larger families had to learn the routine of conversing with the entire small group instead of breaking off into dyads.

Beyond the obvious differences in family size, participants noted that their in-laws had different techniques for conducting conversation, to which they did not always 
know how to respond effectively. For example, a newlywed woman described a conversational pattern with her mother-in-law that she did not know how to bridge:

I don't feel like I make much conversation with her, it's more following along. . . . I would rather that there was more back-and-forth there.... She doesn't let conversations drop. And I think there has to be a bit of a lull before I'll come up with something.

Later in the interview, this woman commented that perhaps her mother-in-law also felt awkward, but that the mother-in-law's conversational routine was to fill up the pauses so that the two of them would not feel awkward, a habit which, in fact, exacerbated the problem. Other participants also indicated that they simply did not know how to converse with their in-laws, but that they wanted both to feel comfortable and to make the other person feel comfortable. Unfortunately, they did not know how to resolve this problem because people do not usually talk about how to conduct conversation. The comfort of family routines for conversations resides, in part, in not having to explain them, precisely because they are routines.

For many families, joking was the routine way of communicating with each other and communicating acceptance of the newcomer. Joking and teasing in families was often used as a way to show the newcomers they were a part of the group. For example, a newlywed explained how her family joked with her husband to communicate acceptance:

Somebody's always the butt of the jokes.... That's how my family helps my husband feel comfortable is by making fun of him.... Whenever my dad made a joke about him, he knew that he was welcome in the family.

Similarly, another participant reported how her brother's new wife came to fit into the family routine of joking:

My dad is a big teaser. ... He loves to tease people. And that is kind of how he welcomed [my sister-in-law] into the family. ... And the amazing thing is after [she] figured out what he was doing, she just shot right back.

However, sometimes the newcomers were not accustomed to being kidded with; therefore, it took a while before they learned what the joking meant. One newlywed woman pointed out how her husband had not quite adjusted to her family's routine of joking: "I think [my husband] had to learn how to be more sarcastic with [my family]. ... And how to take it better. [His] family really isn't sarcastic." Families that engaged in a lot of joking as a routine considered it a way to signal acceptance, but sometimes they did not recognize that the newcomer was uncomfortable with the joking because he/she came from a different family with a different routine.

As Socha (1997) has suggested, communication patterns in families tend to persist over generations. However, because families are groups with permeable boundaries, as families assimilate newcomers they are introduced to new communication styles that motivate them to examine their own routines. As a result, families experience the two-way process of assimilation (Anderson et al., 1999), with pressure to maintain 
the routines coming from the family, countered by pressure to change coming from the newcomer and, as we shall see, from other group members.

\section{Newcomers' Perceptions and Responses}

As reported by participants from all groups, newcomers to the family had different perceptions of and responses to the family routines. When entering families that had routines similar to their own families of origin, such as playing games or watching movies, newcomers had no problems assimilating into this part of family life.

Exposure to different family routines caused some newcomers to re-evaluate their own family experiences and question the underlying values. They sought out the motivation of the action and the unacknowledged circumstances that influenced the families' routines. After exploring this higher level of knowledge about their family's routines, the newcomers came to realize that what they had deemed acceptable or unacceptable communication routines within their own families of origin could be reframed and re-evaluated within the value systems of their new families. For example, from interacting with her more upbeat in-laws, one married participant realized that her mother's negative and cautious approach to life was not useful in everyday life. Similarly, what she had previously judged as superfluous "touchy-feely" verbal affirmation among members of her husband's family actually felt good and helped her feel more confident and secure. Similarly, two newlywed men realized that there was something lacking in the routines of their own families of origin concerning the importance of family togetherness and contact. Thus, through the routines of their in-laws, they learned new values about what it meant to be a family. As these examples suggest, by being exposed to new routines and norms in family life, newcomers sometimes began to re-evaluate their own family routines and came to realize that there was more than one way to conduct family living.

In other cases, when the routines conflicted with their concept of acceptable adult family life, participants openly rebelled against the routines. Some of the newcomers were not happy with the level of control implied by the routines of the families they had entered, or the values reflected in them. For example, one participant reported that her brother-in-law, at first, did not like her family's celebrations, denouncing their practice of birthday parties as "ridiculous" and "materialistic." The brother-inlaw felt the family's celebrations were excessive and put too much emphasis on things. He did not like the pressure to participate in a routine that did not reflect his own values. Another issue for many of the newcomers was that they perceived some of the routines as childish, and they wanted to exert their independence from family expectations. For example, most of the newly married participants expressed conflict about being expected to spend weekends, holidays, or vacation time with their inlaws in very specific ways. One newlywed complained about his in-laws' expectations for celebrating Thanksgiving: "I got a day off, so why do I have to go to 14 different places ... to spend time? Why can't I just sit around in my sweat pants all day?" The response of the newcomers to this felt pressure and control was to rebel against it, 
which might be expressed in direct communication, passive-aggressive behavior, avoidance, or mediated communication through the spouse.

In response to perceived different routines, some newcomers found an opportunity to create or accept a role in their spouse's family that they did not hold in their own family. Almost all the participants in all groups described the primary role for the newcomer in the family as supporter of the spouse, a role which the newcomer usually accepted. As long as that primary role was suitably executed, all participants expressed that they should be and would be satisfied with the newcomer, no matter what the other shortcomings or differences were. Beyond those basic primary roles, participants also reported other roles for the newcomer, often created by the newcomers as they sought to place themselves comfortably in the family. For example, two participants positioned themselves as entertainers by often playing their guitars and singing at family gatherings. A daughter-in-law volunteered to help her mother-in-law in the kitchen when the daughter-in-law realized that no-one else in the family helped the mother. Two newlywed men lightened up family interactions by playing the jokester and keeping the conversation light. Other newlyweds started hanging out with the children at extended family gatherings and found that they felt most comfortable entertaining and playing with them. The newcomers accepted or created these roles as a way to be useful to and maintain positive relationships with their spouse's families. Thus, they saw themselves fitting into the routines of the family and being accepted, and as positioning themselves to effect change in those routines.

\section{Change in Communication Routines and its Repercussions}

Through the medium of the routines from both of their families of origin, the new couples instituted new routines for themselves and for their families of origin. In some cases, the new routines communicated their status as a unit separate from either set of parents. Sometimes, however, the families instituted the change to help the couple establish its own identity, for example by not expecting the newlyweds to attend family events as frequently or to phone every day as they had before marriage. In other cases, newlyweds planned to institute new routines not only as a way to establish themselves as a couple, but also as a way to mitigate the tension of having to honor and include both of their families of origin. For example, most of the married or engaged participants planned to celebrate holidays at their own homes when they had children instead of shuttling between in-laws.

Most of the participants reported that both sets of in-laws had merged, at times, to create new routines that embraced their conjoined families. Often, this occurred when the newcomer came from a small family with a single parent. Thus, it was easy to include the parent who would otherwise be alone. For example, one sibling-in-law reported that, after his sister married, the husband's mother was always included in their family get-togethers, which he saw as "very natural ... she's just a part of the family." Similarly, a newlywed explained how his mother was invited to his in-laws' celebrations: 
My mom was going to be on her own on Thanksgiving. And [my wife's mother] e-mailed my mom ... "Why don't you come by our family's house for Thanksgiving?" ... And it was actually quite a pleasant experience.

In other families, the two sets of in-laws found that they liked each other and had similar interests, or that it was easier to share their children and grandchildren by having joint celebrations. For example, since one newlywed couple lived far away from the parents, when the couple drove back to visit, one set of parents would invite the other set over the first evening so that they would not have to wait to see their child. Many of the parents-in-law, newlyweds, and siblings-in-law reported that inviting both sets of in-laws to family celebrations was a natural way to reduce stress on the newlyweds to spend equal amounts of time with both families as well as a way to extend their own families. This practice, which illustrates the characteristic of bona fide groups as having permeable boundaries and being interdependent with their context (Stohl \& Putnam, 1994), has not been reported in other studies of in-laws.

Pressure to change family routines also originated in family members other than the newcomer. As Keyton (1999) suggested, relationships within a group are not uniform; members have different relationships and communication patterns with different group members. In this study, participants reported that siblings often forged their own new routines with their married brothers and sisters to establish their individual adult identities and to renegotiate their family-of-origin routines. Many siblings-in-law discovered that the spouse of their sibling became a new adult voice in their lives, one who was accepted and trusted by the parents, but who offered opinions in contrast to those of the parents. For example, these participants mentioned how the spouses of their siblings had become advisers on such things as the transition to college, where to go for spring break, workout routines, trip directions, servicing the car, etc. Many younger siblings called their brothers- or sisters-in-law instead of their parents when they needed advice or help on specific matters:

[My future sister-in-law] went here for undergrad, and so last year, my first freshman year, I would go over to her house all the time, and always call her up and ask her ... because I didn't know the area.

These younger siblings found they could turn to the newcomer for advice and be treated as an adult, in contrast to the responses of their parents who might not recognize the adult needs or interests of their younger children. These direct, unmediated relationships resulted in the siblings creating new routines among themselves that often did not involve the parents at all. For example, in many families the married children and their spouses began to visit and interact with the unmarried children without the parents, and thereby established their own communication routines.

These direct relationships were important to the siblings-in-law because they served to transform the family of origin from a child-centered family into an adultcentered family. The newcomers found that their siblings-in-law welcomed them into the family because the newcomers brought new ideas and attitudes that reflected the 
emerging adulthood of the younger siblings-in-law. Through having direct relationships with their siblings' spouses, younger siblings found a space to become adults under the influence and protection of the in-law. In this way, the newcomer acted as a catalyst for transforming the family of childhood into a family of adults. Thus, the relationship between the newcomer and the spouse's siblings established that the family would continue as a family, even as the children became adults and, perhaps more importantly, that the adult children would be recognized as adults in this transformed family.

Another re-created routine experienced by some participants was that of changed relationships between parents and married children. These changes reflect the influence of the context (Stohl \& Putnam, 1994) and other group membership (Keyton, 1999) on the bona fide group. Most of these changes were positive. Some parents reported that, when their children married, they were able to establish adult relationships with them. For example, one mother commented, "This has given me a new relationship with my daughter. ... We're more equal." Another mother described the change as opening up "a whole new area of things we can talk about." Although this transformation to adult relationships might have occurred eventually without the child's marriage, these and other participants noted that, even though their children had lived on their own before marriage, the real change in their relationships occurred when the children married. Through this communication change, participants realized that although they might communicate less often with their married children, their communication was in some respects more intimate now because they could communicate as adults who had adult perspectives on marriage and family life. Thus, they created a new communication routine which transformed the family of childhood into a family of adults.

Some newlyweds also commented on how contact with their spouse's families had encouraged them to improve communication with their own families of origin, again demonstrating how bona fide groups are influenced by other group membership. Sometimes, the impetus to renew communication came from being exposed to the spouse's closely knit family, which made newlyweds appreciate their ties to their own families. In addition, sometimes the in-laws encouraged the newcomers to reach out and heal problematic relationships in their families of origin. For example, one newlywed man found that his in-laws encouraged him to see his own mother more often; when he did, he found this problematic relationship improved, which also eased the in-law tension between his mother and his wife.

However, not all families experienced changes for the better in the communication routines between parent and child. Some daughters, particularly, felt a new reticence about discussing their marital relationships with their parents. For example, one newlywed found that, although she had been very close to her mother, she could not talk to her mother about her husband because the mother was jealous of the time spent with his family. Participants who had experienced negative change in communication routines regretted them but did not know how to resolve them. As a result, these participants felt uncomfortable in their families of origin, and the newcomers were not fully assimilated. 


\section{Discussion}

In this study, through the lens of structuration theory, assimilation of newcomers into the family emerged as a two-way process of communicating and negotiating routines and norms. This process illustrates how families communicate their routines to newcomers, how the newcomers respond to those routines, and how the whole family as a group adjusts to the newcomer using different kinds of knowledge about the routines while attempting to maintain the ontological security of family life. A related outcome of the study was identification of specific communication routines in families.

In response to the newcomers, all the participants in this study, whether parentsin-law, siblings-in-law, or children-in-law, discovered that their group routines were not the only way to conduct family living. For example, although families expected holiday festivities and family gatherings to continue as they always had, they were willing to make some concessions to accommodate the newcomer and also to recognize or even include the other in-law family. As the other children in the family entered adulthood, the married siblings, their spouses, and the unmarried siblings instituted new routines among themselves to create a new family of adulthood that created a new sense of ontological security because it acknowledged their adult status and maintained some of their familiar childhood routines.

However, for all participants, this process of adjusting to the newcomer and restoring ontological security was incomplete, and they all experienced some discomfort which they hoped would improve over time or which they simply accepted as an inevitable outcome of change. At the same time, however, most families expected that they would have to change in some way to accommodate the newcomer. Some routines were sacred to the family while others were more easily negotiated. Against the background of the family's routines, many members of the family often recognized that the couple needed to be its own entity and establish its own routines and that, in the end, the couple's personal routines would and should become more important to the couple than those of the families of origin. Although all the participants recognized that this autonomy of the couple was the ideal in theory, nevertheless many parents-in-law particularly longed for the re-establishment of their family routines and their own parental authority, wanting to see the spouses of their adult married children as simply "one of the kids." In a way, they did not want to acknowledge that their married children belonged to other family groups. This changing of the dynamics in the family wrought by the entry of the newcomer disrupted the ontological security of the family because the married children no longer belonged just to one family.

Sometimes, the newlyweds themselves were implicated in contributing to the discomfort of the newcomer in entering the family. The newlyweds often had not evaluated their own routines and had expected their newcomer spouses to fit in with their families of origin, with the attitude "You love me, you'll love my family." Although this attitude was appropriate in regard to some family routines, nevertheless the children had grown up and changed their routines and sometimes values, 
but they had not always revealed that change to their parents. These adult children maintained their ontological security associated with home by continuing to enact their childhood relationships with their parents by continuing the same routines (Giddens, 1984). The child was, therefore, reluctant to broach changes in those routines that needed to be made in order to accommodate not only the newcomer spouse, but also the new adult status of the married child. Sometimes, the newcomer was placed in the uncomfortable position of appearing to be the one who objected to the family routine, the one who wanted a change, when, in fact, the change was necessary to acknowledge the adult status of the married child. Therefore, the newcomer could easily become the scapegoat, and be blamed for changes in family routines. The newcomer had to ask the spouse, as one participant phrased it, to "step up" to a new relationship with his/her parents, that of adult on equal footing with the parents and worthy of respect and deference in recognition of his/her adult status. This new status of the child changed the dynamics within the family, as well as the routines, because family members had to recognize that the child was now the member of other families and other groups, as well as an adult in his/her own right.

The practice of the spouse mediating the relationship between the newcomer and the family has both positive and negative repercussions. The practice avoids open conflict in the family, shelters family members from inappropriate messages, and shields them from the concomitant negative emotions. In addition, by mediating the relationship, the spouse can own up to his/her own changes or demands for adult status in the family instead of allowing the newcomer to be blamed. Despite these positive outcomes, long-term routinized mediation of the relationship positions the newcomer as an outsider in the family forever.

The siblings-in-law, however, were more likely to develop unmediated relationships with the newcomer and to welcome openly the changes wrought by them as desirable because the changes moved the whole family to acknowledge the adult status of all members. Younger siblings recognized that family gatherings would not maintain their childhood excitement as the children of the family became adults. In other words, although younger siblings might feel awkward in changing their longstanding routines of family life to accommodate a new sibling-in-law, the younger siblings also recognized that these changes would eventually accommodate them and their future spouses when they reached full adult status.

The evidence from these participants illustrates how family communication routines can be the most problematic routines for in-laws because communication routines are usually implicit. It is relatively easy to negotiate openly how to alter holiday celebrations in terms of times and rituals or how to split time between two in-law families, but people do not usually negotiate how much emotional display, how much joking, what conversational topics, and what conversational patterns are appropriate. Interactants may not even be sensitive to the differences between them, much less know how to adjust their own behavior to make each other comfortable. Thus, newcomers and their in-laws may long feel uncomfortable because their communication routines remain at odds, even though they have worked 
out time-sharing, holidays, and other routines. Thus, by maintaining the communication routines of the earlier family of origin, when the offspring were minors, families may not fully assimilate the newcomer spouses.

Analysis of the three kinds of knowledge that underlie routines, as proposed by Giddens (1984), reveals how people process and come to understand their experiences of negotiating routines with or as newcomers in the group. In this study, examples of each kind of knowledge emerged as participants tried to articulate and understand their own and their in-laws' routines.

The first level of understanding is practical knowledge of everyday routines and norms. Families, like other groups, enact their everyday interactions in routines that have been the norm for as long as they can remember. As a result, in response to a newcomer, families attempted to assimilate the newcomers by carrying on as usual and expecting the newcomer to learn, adjust, and fit in. The implicit message from such behavior is "If you want to be one of us, then act like us" - an attitude that embodies the concept of practical knowledge. When the family members conducted their routines as usual, they believed they were conveying the relational message that the newcomer was considered family.

However, when the routines of the family did not make sense to the newcomer, the family members had to share their rationalized knowledge about their group behavior and explain it to the newcomer along with their expectations for compliance. This occurred when the family explained the family history and relationships to the newcomer and directly told the newcomer what was expected of him/her. In addition, the routine of creating a mediated relationship with the newcomer was a way of passing on rationalized knowledge. In this practice, the spouse of the newcomer was put in the position of explaining the routines of the family to the newcomer and explaining the newcomer's perspective to the family.

The third kind of knowledge, of the motivation of action, was also evident. Families reacted to the stereotypes of problematic in-laws that they received from media messages and narratives from acquaintances. To combat those stereotypes, participants in this study attempted to engage the newcomer in healthy communication routines that recognized the newcomer's presence and influence in the family. Similarly, the newcomers evaluated the routines they had grown up with and recognized the unacknowledged conditions in their families of origin that influenced those routines. The newcomers then sought to change their own responses to the routines and learn something new, or possibly to teach a new routine to the in-law family.

Thus, in many families the entry of the newcomer activated all three kinds of knowledge and moved people to meta-levels of thinking about family behaviors and routines. In this study, when people moved to these higher levels of knowledge, they were able to react to the changes in their families in more positive ways and began to seek understanding of the in-law rather than simple compliance. 


\section{Practical Applications and Implications for Other Groups}

This study suggests a new perspective with which to frame the disruption caused by newcomers, in both families and other groups. The changes caused by the newcomer could be framed in three ways: (a) as a sign of misunderstanding the motivation behind the group or individual routines; (b) as reflecting changes that are as yet unseen, but occurring in other group members; and (c) as an opportunity to introduce new values, routines, or roles into the group.

The findings of this study suggest that the discomfort in families created by the entry of an in-law might be beneficially reframed as a clash of communication routines rather than as a clash of personalities. Therapists helping clients with in-law issues might be able to de-escalate the emotions of in-law problems by approaching them from a communication routines-based perspective. Rather than singling out specific problematic family members, the problem may lie in ignoring, miscommunicating, or misunderstanding family routines. Indeed, the identified problematic individual may only be the most visible or most vocal person connected with the issue, reflecting what other family members feel but do not express (McGoldrick, 1988). Family therapists could use the three types of knowledge identified by Giddens (1984) to explore with their clients how family routines have formed, what underlying values they reflect, and how changes in routines disrupt the comfort of the family life. Clients could be encouraged to openly address and question communication routines that make them uncomfortable and to question the underlying motivations for the routines they hold so sacred, rather than to scapegoat an individual. Understanding these factors could lead to greater acceptance of changes wrought by the assimilation of the newcomer.

The insights from this study also suggest that the assimilation of newcomers into other kinds of closely knit groups or work groups might cause similar kinds of discomfort and responses in both the group and newcomer. For example, after a brief introduction or initiation rite, many groups continue with their routines and expect the newcomer to fit in and not change the established routines. Groups, like the families in this study, often believe that their routines are the best and only way to conduct group life. If the newcomer does not understand or concur with the routines, both the group and the newcomer may feel uncomfortable. Families use the practice of mediated relationships between the newcomer and the family to interpret the differences in routines and their underlying motivation, and to negotiate concessions for the newcomer. Non-family groups, however, do not usually specify a person to mediate the relationship between the newcomer and the group; thus, the newcomer may feel that he/she has no influence on the group. Groups that have no specific process by which to assure two-way communication between the newcomer and the group may frequently experience incomplete or failed assimilation. Non-family groups might be counseled to provide an advocate for newcomers to assure that twoway communication and assimilation occur - and then to follow up and consider the perspective of newcomers. This practice may be particularly important for groups that claim that they are "just like family." 
Building awareness of how the assimilation process is experienced by our in-laws may lead to greater understanding in our families, an idea that was also proposed by Limary (2002). Several participants approached me after our interview, commenting on how our conversation had made them think more deeply about their in-law relationships. They had begun to take the process of assimilation more seriously and to examine their own experiences and reactions. These comments have sparked a hope in me that, by looking at this relationship from a different perspective, by seeing it as a process of re-creating and adjusting our routines, rather than as a site for antagonism, we can move beyond the stereotyped media messages and low expectations for relationships with our in-laws.

\section{References}

Anderson, C. M., Riddle, B. L., \& Martin, M. M. (1999). Socialization processes in groups. In L. R. Frey, D. S. Gouran, \& M. S. Poole (Eds.), The handbook of group communication theory and research (pp. 139-163). Thousand Oaks, CA: Sage.

Barker, V. E., Abrams, J. R., Tiyaamornwong, V., Seibold, D. R., Duggan, A., Park, H. S., et al. (2000). New contexts for relational communication in groups. Small Group Research, 31, $470-503$.

Bengston, V. (2001). Beyond the nuclear family: The increasing importance of multigenerational bonds. Journal of Marriage and the Family, 63, 1-16.

Burrell, B., \& Morgan, G. (1979). Sociological paradigms and organisational analysis. Portsmouth, NH: Heinemann.

Carter, B., \& McGoldrick, M. (1988). Overview: The changing family life cycle-a framework for family therapy. In The changing family life cycle: A framework for family therapy (2nd ed., pp. 3-28). New York: Gardner Press.

Cotterill, P. (1989). Mothers and daughters-in-law: A study of intergenerational relationships between family women (Doctoral dissertation, Council for National Academic Awards, UK, 1989). Dissertation Abstracts International, 41(03), 1014A.

Creswell, J. W. (1997). Qualitative inquiry and research design: Choosing among five traditions. Thousand Oaks, CA: Sage.

Duvall, E. (1954). In-laws: Pros and cons. New York: Association Press.

Fischer, L. R. (1983). Mothers and mothers-in-law. Journal of Marriage and the Family, 45, 187-192.

Fitzpatrick, M. A. (1988). Between husbands and wives: Communication in marriage. Newbury Park, CA: Sage.

Frey, L. R. (1994a). Introduction: Revitalizing the study of small group communication. Communication Studies, 45, 1-6.

Frey, L. R. (1994b). The naturalistic paradigm: Studying small groups in the postmodern era. Small Group Research, 25, 551-577.

Giddens, A. (1984). The constitution of society. Cambridge, UK: Polity Press.

Holstein, J. A., \& Gubrium, J. F. (1995). The active interview. Thousand Oaks, CA: Sage.

Jackson, J. C., \& Berg-Cross, L. (1988). Extending the extended family: The mother-in-law and daughter-in-law relationship of black women. Family Relations, 37, 293-297.

Jorgenson, J. (1994). Situated address and the social construction of "in-law" relationships. Southern Communication Journal, 59, 196-204.

Keyton, J. (1999). Relational communication in groups. In L. R. Frey, D. S. Gouran, \& M. S. Poole (Eds.), The handbook of group communication theory and research (pp. 192-222). Thousand Oaks, CA: Sage. 
Limary, B. H. (2002). The mother-in-law/daughter-in-law dyad: Narratives of relational development among in-laws (Doctoral dissertation, University of New Mexico, 2002). Dissertation Abstracts International, 63(02), 773A.

Lopata, H. Z. (1999). In-laws and the concept of family. Marriage and Family Review, 28, 161-172.

McGoldrick, M. (1988). The joining of families through marriage: The new couple. In B. Carter \& M. McGoldrick (Eds.), The changing family life cycle: A framework for family therapy (2nd ed., pp. 212-234). Boston, MA: Allyn and Bacon.

Moreland, R. L., \& Levine, J. M. (1982). Socialization in small groups: Temporal changes in individual-group relations. Advances in Experimental and Social Psychology, 15, 137-192.

Norris, J. E., Pratt, M. W., \& Kuiack, S. L. (2003). Parent-child relations in adulthood: An intergenerational family systems perspective. In L. Kuczynski (Ed.), Handbook of dynamics in parent-child relations (pp. 325-344). Thousand Oaks, CA: Sage.

Nydegger, C. N. (1986). Asymmetrical kin and the problematic son-in-law. In N. Datan, A. L. Greene, \& H. W. Reese (Eds.), Life-span developmental psychology: Intergenerational relations (pp. 99-123). Hillsdale, NJ: Lawrence Erlbaum Associates.

Pfeifer, S. K. (1989). Mothers-in-law's and daughters-in-law's perceptions of interpersonal interaction (Doctoral dissertation, University of Delaware, 1989). Dissertation Abstracts International, 51(05), $1783 \mathrm{~A}$.

Servovich, J. M., \& Price, S. J. (1994). In-law relationships: A role theory perspective. International Journal of Sociology of the Family, 24, 127-146.

Silverstein, J. L. (1990). The problem with in-laws. Journal of Family Therapy, 14, 399-412.

Socha, T. J. (1997). Group communication across the life span. In L. R. Frey \& J. K. Barge (Eds.), Managing group life: Communicating in decision-making groups (pp. 3-28). Boston, MA: Houghton Mifflin.

Socha, T. J. (1999). Communication in family units. In L. R. Frey, D. S. Gouran, \& M. S. Poole (Eds.), The handbook of group communication theory and research (pp. 475-492). Thousand Oaks, CA: Sage.

Stafford, L., \& Dainton, M. (1995). Parent-child communication within the family system. In T. J. Socha \& G. H. Stamp (Eds.), Parents, children, and communication: Frontiers of theory and research (pp. 3-21). Mahwah, NJ: Lawrence Erlbaum.

Stohl, C., \& Putnam, L. L. (1994). Group communication in context: Implications for the study of bona fide groups. In L. R. Frey (Ed.), Group communication in context: Studies of natural groups (pp. 473-481). New York: Knopf.

Strauss, A., \& Corbin, J. (1998). Basics of qualitative research: Techniques and procedures for developing grounded theory (2nd ed). Thousand Oaks, CA: Sage.

van Manen, M. (1990). Researching lived experience: Human science for an action sensitive pedagogy. Albany: State University of New York Press. 
Copyright of Journal of Applied Communication Research is the property of National Communication Association and its content may not be copied or emailed to multiple sites or posted to a listserv without the copyright holder's express written permission. However, users may print, download, or email articles for individual use. 